\title{
Elicitation of tourist accommodation demand for counter-seasonal responses: evidence from the Slovenian Coast
}

\author{
Tina ŠEGOTA ${ }^{\mathrm{a}^{*}}$, Tanja MIHALIČ ${ }^{\mathrm{b}}$, \\ ${ }^{a}$ University of Greenwich, Business School, Department of Marketing, Events and Tourism, \\ Old Royal Naval College, Park Row, London, United Kingdom \\ ${ }^{\mathrm{b}}$ University of Ljubljana, Faculty of Economics, Kardeljeva ploščad 17, Ljubljana, Slovenia \\ *Corresponding author: t.segota@greenwich.ac.uk
}

Acknowledgement: This work was supported by the Slovenian Research Agency [grant number P5-0117]. An earlier version of this paper was presented at the 6th Conference of the International Association for Tourism Economics, June 2017, Rimini, Italy.

\begin{abstract}
This paper aims to survey the seasonality of Slovenian Coast from two different perspectives, namely: (i) major source markets (domestic, main foreign markets); and (ii) accommodation categories (hotels, camps, other). It applies a decomposition of the Gini index method. The results reveal the total Slovene coastal tourism concentration is relatively high, compared to other Mediterranean coastal destinations. However, domestic tourists and tourists from neighbouring markets of Italy and Austria reveal less seasonal pattern overall and across all accommodation categories. Thus, increased efforts to attract more domestic, Italian and Austrian tourists would reduce the seasonality. Further, German and Russian visitors demonstrated higher seasonality pattern. Authors argue that market-specific products to attract tourists out of the peak season need to be developed based on the in-depth analysis of their seasonal behaviour and travel motivation.
\end{abstract}

Keywords: seasonality; tourism demand; accommodation; Gini index; decomposition; Slovenia.

\section{Introduction}

Seasonality has long been a major problem of the tourism industry, especially in destinations subject to climate and weather conditions (Butler, 2001). Thus, tourism destinations have had an imperative to identify and establish policies and strategies aiming to minimise the negative impacts of seasonality. These policies and strategies entail a diversification of the product mix (Andriotis, 2005), pricing incentives such as discounts and special offers (Andriotis, 2005; Butler, 2001), the attraction of new market segments (Cisneros-Martínez \& FernándezMorales, 2013; Fernandez-Morales, Cisneros-Martinez, \& McCabe, 2016; Fernandez-Morales \& Mayorga-Toledano, 2008), regulation of holidays (Cannas, 2012; Rosselló \& Sansó, 2017) or simply embrace the regular occurrence of seasonality (Andriotis, 2005; Fernandez-Morales, 2003). 
There are various definitions of seasonality. Butler (2001) distinguishes between natural and institutional seasonality: the former refers to climate and weather conditions of tourism destinations, whereas the latter relates to 'traditional and often legislated temporal visitations in human activities and inactivity' (Butler, 2001, p. 6). By following Allcock's (1994) definition, Butler (2001) also referred to seasonality as the tendency of tourist flows to become concentrated in short periods of the year, causing a temporal imbalance which relates to the peaking and overuse of facilities. This leads to short operating seasons which leave the tourism industry with under-utilised facilities, a lack of full-time employment and staff retention, and being incapable of attracting inward investments (Butler, 2001; Krakover, 2000; Pearce, 1989; Yacoumis, 1980). Moreover, hotel managers and owners very often attribute low occupancy rates in the high season to the temporal imbalance of tourism demand and the oversupply of beds offered by 'parahoteleriai' (Andriotis, 2005).

More recently, several studies on seasonality in sun and beach tourism destinations emerged in the tourism economics literature, emphasising that the destinations face high seasonality, forcing tourism managers and policy-makers to come up with effective counterseasonal responses. Although Slovenian tourism has a strong seasonal character (Mihalič, 2011), the seasonality research has predominately focused on Italian (Cuccia \& Rizzo, 2011; De Cantis, Ferrante, \& Vaccina, 2011; Volo, 2010), Croatian (Kožić, 2013; Kožić, Krešić, \& Boranić-Živoder, 2013) and Spanish destinations (Cisneros-Martínez \& Fernández-Morales, 2013; Cunado, Gil-Alana, \& Perez de Garcia, 2005; Duro, 2016; Fernandez-Morales, 2003; Fernandez-Morales et al., 2016; Fernandez-Morales \& Mayorga-Toledano, 2008; Nadal, Font, \& Rossello, 2004; Rosselló \& Sansó, 2017). However, the counter-seasonal responses identified by the above researchers may not be appropriate for Slovenia. Further, the proposed counter-seasonal responses were mainly based on hotel occupancy rates (Cunado, Gil-Alana, \& Péres De Gracia, 2004; De Cantis et al., 2011; Duro, 2016; Fernandez-Morales \& MayorgaToledano, 2008; Volo, 2010), thus disregarding other accommodation facilities such as camps, guest houses, self-catering accommodation, youth accommodation, tourism farms etc. This over research on the data from hotels narrows the insights into wider accommodation demand across different tourism markets, which may result in either inefficient overall counter-seasonal responses or limited marketing opportunities.

Therefore, the purpose of this paper is to survey the seasonality of the Slovenian Coast, stressing the demand for various accommodation facilities across different tourism markets. By decomposing the Gini index and calculating the relative marginal effect (hereinafter RME) as effective tools for surveying seasonality (Fernandez-Morales \& Mayorga-Toledano, 2008), we aim to present counter-seasonal responses that would aid tourism managers and policymakers in creating policies and strategies for the sustainable development of tourism (Mihalič, 2016).

\section{Literature review}

\subsection{Aspects of tourism seasonality}

\subsubsection{Determinants of seasonality in tourism}

The general consensus is that tourism is subject to natural and institutional seasonality (Butler, 2001), which are very often complementary rather than unrelated events. A destination's climatic conditions, such as day length, insolation, the temperature of the air and sea (or rivers and lakes), relative humidity, rainfall etc, are considered determinants of natural seasonality (Mihalič \& Kaspar, 1996). On the other hand, institutional seasonality results from human decisions concerning the time to take a vacation, which is influenced by religion, culture, ethnicity, fashion, and socio-political factors (BarOn, 1975; Butler, 2001; Hartman, 1986). 
Natural and institutional seasonality thus predetermine the availability of natural, social and cultural attractions and related activities, but also affect vacation traditions, the institutionalisation of holidays, and the changing tastes of visitors.

According to Koenig-Lewis and Bischoff (2005), these determinants trigger 'at the same place, at the same time' an influx of tourists, regarding which Butler and Mao (1997) identified three basic patterns - non-peak, one-peak and two-peak. Non-peak seasonality means that tourism activities occur throughout the year (Karamustafa \& Ulama, 2010). One-peak seasonality is represented by tourism activities occurring in specific months, with no or little activity during the rest of the year. Such examples are sun and beach tourism destinations, for which it has been shown that the majority of tourist visitation occurs during the warm summer months (Andriotis, 2005; Fernandez-Morales, 2003; Kožić, 2013; Nadal et al., 2004; Volo, 2010). Two-peak seasonality refers to tourism activities in two seasons (Karamustafa \& Ulama, 2010). And it is the latter two patterns (i.e. one-peak and two-peak) that make up the essence of the seasonality problem: 'an uneven distribution of use over time (peaking) "...that is..." causing inefficient resource use, loss of profit potential, strain on social and ecological carrying capacities, and administrative scheduling difficulties' (Manning \& Powers, 1984, p. 25). As expressed by Trajkov, Biljan, and Andreeski (2016), these peaks or short intervals of tourist concentration are repeated yearly, making them difficult to change or mitigate.

\subsubsection{Negative and positive outcomes of seasonality}

Regardless of its origins, 'seasonality has frequently been viewed as a major problem for the tourism industry, and has been held responsible for creating or exacerbating a number of difficulties faced by the industry' (Butler, 2001, p. 5). Accordingly, the dominant perceptions are that seasonality has negative impacts on the tourism industry, whereas some authors also argue that seasonality can benefit destinations.

Negative economic impacts are related to an increase in prices, income instability and recruiting costs (Ball, 1989; Jang, 2004; Krakover, 2000), resource utilisation (Commons \& Page, 2001; Jang, 2004; Jeffrey \& Hubbard, 1988; van der Werff, 1980) and employment (Ball, 1989; Clarke, 1981; Commons \& Page, 2001; Goulding, Baum, \& Morrison, 2005; Krakover, 2000). Negative environmental and socio-cultural impacts of seasonality have also been researched, with emphasis being placed on the deterioration of landscapes and the disturbance to wildlife, and the decrease in local residents' quality of life due to congestion and crowding (Butler, 2001; Cuccia \& Rizzo, 2011; Mathieson \& Wall, 1982; Muir \& Chester, 1993; Murphy, 1985; Pearce, 1989; Witt \& Moutinho, 1994). According to Jang (2004), crowding also reduces visitors' satisfaction and results in overall low-quality holidays for tourists due to the reduction of available accommodation (Krakover, 2000), and transportation system and infrastructure overuse (Commons \& Page, 2001).

On the other hand, Grant et al. (1997) suggested that the off-season is usually a time when maintenance work on buildings and attractions is scheduled, whilst Murphy (1985) noted that many communities relieve the stress accumulated during the peak season, which helps to 'normalise' the traditional social patterns that have been disrupted. Moreover, Butler (2001) and Hartman (1986) suggested that the off-season allows fragile environments in highly seasonal destinations to rejuvenate and recuperate so that visitors can again admire its fragile nature once the visitations re-start.

\subsubsection{Responses to seasonality}

There are several approaches to managing seasonality (Butler, 2001; Jang, 2004; Koenig-Lewis $\&$ Bischoff, 2005). The first is to develop appropriate tourism products that include all-weather activities and facilities (Andriotis, 2005). The second approach relates to different pricing 
incentives (i.e. discounts and special offers) during the off-season (Andriotis, 2005; Butler, 2001). Baum and Hagen (1999) believe that this approach might damage the business in the long run since aggressive pricing might do more to damage a destination's overall reputation. The third approach refers to attracting new market segments in the off-season periods, with researchers proposing to focus on attracting tourists whose activities would not be too weathersensitive. For example, in the case of Andalusia, Cisneros-Mártinez and Fernández-Morales (2015) suggested a focus on domestic tourists interested in cultural attractions and activities. Similarly, Fernández-Morales and Mayorga-Toledano (2008) proposed attracting British and Nordic tourists in winter months to Costa del Sol in Spain.

Finally, another approach is to develop so-called seasonality coping mechanisms (Andriotis, 2005; Nunkoo \& Ramkissoon, 2011), which have been considered economically unattractive. The ultimate rigorous measures of the tourism industry would be to either close some facilities in order to save costs 'when it is not possible to increase the demand outside the peak season substantially' (Koenig-Lewis \& Bischoff, 2005, p. 213) or to carry out some renovation works in the off-season aiming to improve tourism infrastructure and services (Mathieson \& Wall, 1982; Weaver \& Oppermann, 2000).

\subsection{Measurement of tourism seasonality}

The number of visitors is the most frequent measurement unit of seasonality (Lundtorp, 2001). Other units are the number of arrivals, departures, overnight stays, and tourist expenditures (Karamustafa \& Ulama, 2010). In contrast, the seasonality ratio, the seasonality indicator, the seasonality index, and the Gini index are recognised as the methods most commonly used for measuring seasonality (Karamustafa \& Ulama, 2010; Lundtorp, 2001).

Karamustafa and Ulama (2010) and Lundtorp (2001) compared these four different measurements of seasonality and exposed their strengths and weaknesses. First, the seasonality ratio determines the seasonal demand structure in a year and is calculated 'by taking the highest number of visitors "in a year" and dividing these by the average number of visitors "in that year"' (Karamustafa \& Ulama, 2010, p. 197). The ratio can vary between 1 and 12, with 1 indicating constant visitations for every month and 12 indicating visitations are concentrated in a specific month. Thus, the ratio was perceived to be appropriate for measuring seasonality intensity; but its weaknesses lay in neglecting the skewness of visitation distribution, disregarding the influence of the extreme values and its focus on one-year data only. Second, the seasonality indictor is the inverse of the seasonality ratio and also implies a capacity use measure. It ranges from $1 / 12$ to 1 , with 1 indicating constant visitations during each month, and 1/12 indicating concentrated visitations in a specific month. It aids in calculating the seasonal capacity of accommodation facilities, but it also neglects the skewness of visitation distribution, the influence of extreme values, and only focuses on one-year data. Third, the seasonality index signifies the degree of seasonal variations. Its calculation is based on moving averages and is very useful for forecasting demand because it relies on previous-year data. At the same time, it is the latter that is the key to its weakness since a large amount of data is required to estimate it. Lastly, the Gini index (otherwise known as the Gini coefficient) is used for analysing the seasonal concentration of tourism demand. It ranges from 0 to 1 , where smaller values indicate lower levels of seasonal concentration and greater values indicate substantial concentration. It is considered a seasonality measure that is more sensitive to variations outside the peak season (Fernandez-Morales \& Mayorga-Toledano, 2008), shows greater stability (Lundtorp, 2001) and is less influenced by extreme values (Wanhill, 1980). However, Karamstafa and Ulama (2010) warn that the Gini index is too dependent on seasonal fluctuations and thus conclusions on the monthly distribution of tourists may be insufficient. It was suggested that the seasonality studies should complement the Gini index analysis with 
other seasonality indicator analysis, such as the Theil coefficient (Duro, 2016; Rosselló \& Sansó, 2017) or seasonality coefficient (Trajkov et al., 2016) for inclusion of intra-monthly and inter-weekly fluctuations. Despite these weaknesses, the Gini index has been recognised as being the most widely used in tourism studies aiding in the provision of annual concentration indices (Fernandez-Morales, 2003; Karamustafa \& Ulama, 2010; Lundtorp, 2001; Nadal et al., 2004). Further, by marginally decomposing the Gini index many researchers (CisnerosMartínez \& Fernández-Morales, 2013; Duro, 2016; Fernandez-Morales \& Mayorga-Toledano, 2008; Halpern, 2011) were able to report the contribution of different market segments to the total seasonal concentration at a destination. In our case, the Gini index represents a valuable tool for understanding distributional changes taking place around the summer months when visits to the Slovenian Coast are the most frequent. Moreover, by decomposing the Gini index we aim at reflecting the dissimilarities among tourism markets and revealing the internal differences for demand of accommodation facilities, which would aid in guiding recommendations for how to deal with tourist seasonal variations in Slovenian Coast.

\section{Methodology and data}

\subsection{The decomposition of the Gini index}

Marginal decomposition of the Gini index was proposed by Lerman and Yitzhaki (1985). As such, it provides information on different markets' contribution to the seasonal concentration (Cisneros-Martínez \& Fernández-Morales, 2013; Fernandez-Morales et al., 2016; FernandezMorales \& Mayorga-Toledano, 2008; Halpern, 2011). In line with the purpose of this paper, the decomposition of the Gini index is expressed by the equations presented below.

First, this paper uses Equation 1 to explore the annual concentration of visitors on the Slovenian Coast, which is applied to the number of overnight stays.

Legend:

$$
\mathrm{G}=\left|1-\sum_{i=1}^{N}\left(\sigma X_{i}-\sigma X_{i-1}\right)\left(\sigma Y_{i}-\sigma Y_{i-1}\right)\right|
$$

$\mathrm{G}=$ total annual Gini index

$\mathrm{X}=$ fractions of the number of months in a year

$\mathrm{Y}=$ number of overnight stays

$\sigma \mathrm{X}=$ cumulative percentages of $\mathrm{X}^{\prime} \mathrm{s}$ (in fractions)

$\sigma \mathrm{Y}=$ cumulative percentage of $\mathrm{Y}^{\prime} \mathrm{s}$ (in fractions)

$\mathrm{N}=$ number of months

The range of the Gini index is between 0 and 1 , where $\mathrm{G}$ equals 0 when the 12 -monthly data are equal, i.e. there is perfect equality among the months in the concentration of visitors at a destination. On the other hand, $G$ equals 1 indicates complete inequality among the monthly concentrations of visitors. Thus, the greater the Gini index, the greater the inequality in annual concentration.

Second, Equations 2 and 3 represent the decomposition of the Gini index as suggested by Lerman and Yitzhaki (1985). Here, for example, we can breakdown the number of overnight stays into two markets: domestic tourists $\left(Y^{1}\right)$ and international tourists $\left(Y^{2}\right)$, which in this case sets $K=2$. In the case of decomposing the Gini index by the type of accommodation, we can distinguish between hotels $\left(Y^{l}\right)$, camps $\left(Y^{2}\right)$ and other accommodation $\left(Y^{3}\right)$, so in this case, $K=3$. 


$$
G=\sum_{k=1}^{k} G_{k} S_{k} R_{k}
$$

Legend:

$\mathrm{G}=$ total annual Gini index

$\mathrm{G}_{\mathrm{k}}=$ annual Gini index of market $\mathrm{k}$

$\mathrm{k}=$ market $(\mathrm{k}=1 \ldots \mathrm{n})$

$\mathrm{S}_{\mathrm{k}}=$ share of market $\mathrm{k}$ in total tourist demand

$\mathrm{R}_{\mathrm{k}} \mathrm{ii}=\operatorname{cov}\left(\mathrm{Y}_{\mathrm{k}}, \mathrm{F}\right) / \operatorname{cov}\left(\mathrm{Y}_{\mathrm{k}}, \mathrm{F}_{\mathrm{k}}\right)$

$\mathrm{F}=$ distribution function of $\mathrm{Y}$

$Y=$ number of overnight stays

$\mathrm{F}_{\mathrm{k}}=$ distribution function of $\mathrm{Y}_{\mathrm{k}}$

From Equation 2 we can also see that the contribution of each market $\left(C_{k}\right)$ to the seasonal concentration depends on $G_{k}, S_{k}$ and $R_{k}$ (i.e. $C_{k}=G_{k} S_{k} R_{k}$ ). Thus, we expressed the contribution of each market in relative terms as the share of inequality of component $k$ : $G_{k} S_{k}$ $R_{k} / G$. This decomposition enables the calculation of relative marginal effects $(R M E)$ where a proportional increase in a market $e^{k}$ (equally distributed throughout the year) will reduce or enhance seasonal concentration. This is represented by equation 3 .

Legend:

$$
R M E_{k}=\frac{\partial G / \partial e^{k}}{G}=S_{k}\left(\frac{R_{k} G_{k}}{G}-1\right)
$$

$\mathrm{RME}_{\mathrm{k}}=$ relative marginal effect of market $\mathrm{k}$

$\mathrm{k}=$ market $(\mathrm{k}=1 \ldots \mathrm{n})$

$\mathrm{G}=$ total annual Gini index

$\mathrm{G}_{\mathrm{k}}=$ annual Gini index of market $\mathrm{k}$

$\mathrm{S}_{\mathrm{k}}=$ share of market $\mathrm{k}$ in total tourist demand

$\mathrm{R}_{\mathrm{k}}=\operatorname{cov}\left(\mathrm{Y}_{\mathrm{k}}, \mathrm{F}\right) / \operatorname{cov}\left(\mathrm{Y}_{\mathrm{k}}, \mathrm{F}_{\mathrm{k}}\right)$

$\mathrm{e}^{\mathrm{k}}=$ percentage change in market $\mathrm{k}$

$\mathrm{R}_{\mathrm{k}}=\operatorname{cov}\left(\mathrm{Y}_{\mathrm{k}}, \mathrm{F}\right) / \operatorname{cov}\left(\mathrm{Y}_{\mathrm{k}}, \mathrm{F}_{\mathrm{k}}\right)$

$\mathrm{F}=$ distribution function of $\mathrm{Y}$

$\mathrm{Y}=$ number of overnight stays

$\mathrm{F}_{\mathrm{k}}=$ distribution function of $\mathrm{Y}_{\mathrm{k}}$

\subsection{Data}

In this paper, tourism demand is measured by the number of overnight stays in hotels, camps and other accommodation on the Slovenian Coast made by the top five markets. The data were obtained from the series of monthly surveys of tourist activities prepared by the Statistical Office of the Republic of Slovenia (hereinafter SORS). In 2010, the SORS changed its datagathering methodology; therefore, we will focus on the period 2010-2014 for which the data are available per tourist accommodation and business entity. Further, the Slovenian Coast is represented by four municipalities, which are aggregated under the joint category 'Seaside resorts'.

The data on overnight stays by different accommodation type facilities were grouped into three categories: (1) hotels and similar accommodation establishments (hereinafter hotels), which included hotels, motels, boarding houses, inns and overnight accommodation; (2) camping sites (hereinafter camps); and (3) other accommodation establishments (hereinafter other accommodation), which included apartment settlements, tourist farms with accommodation, private accommodation (i.e. rented rooms, dwellings), mountain huts, company vacation facilities, youth hostels, vacation facilities for youth, other accommodation 
facilities, temporary accommodation facilities, and marinas. In the period 2010-2014 hotels operated throughout the year, whilst camps and other accommodation operated from six to eight months (six months in total in 2013, eight months in total in 2010, and seven months in total in the other years of the period, respectively). Moreover, the criterion on the top five markets by the number of overnight stays on the Slovenian Coast resulted in collecting data for Slovenians, Italians, Austrians, Germans and Russians (SORS, 2015).

\section{The Slovenian Coast and its tourism}

The Slovenian Coast is located in the southwest of the country: it stretches along $46.6 \mathrm{~km}$ in the far north of the Adriatic Sea and is classified as a mainland coastal destination. The region encompasses four municipalities - Ankaran, Koper, Izola and Piran. These are perceived as important contributors to Slovenian tourism since they account for $25.8 \%$ of all Slovenian overnight stays by domestic tourists, $19.6 \%$ of all Slovenian overnight stays by international tourists, and $20 \%$ of all Slovenian accommodation capacities (SORS, 2015). The Municipality of Piran is the most popular among international tourists (64.6\% of its total overnight stays), whereas Koper and Izola are more popular among domestic tourists (53.3\% and 59.4\% of their total overnight stays, respectively) (SORS, 2015).

The Slovenian Coast has a long history of tourism - its mild climate and the beneficial effects of seawater made it a famous healing resort from the $13^{\text {th }}$ century onwards (Tourism Piran-Portoroz, 2013). But, its tourism development was boosted in the $19^{\text {th }}$ century with the construction of the infamous Hotel Palace and its gambling salon (Tourism Piran-Portoroz, 2013). The tourism development also includes its rich natural resources and cultural heritage. For example, the Sečovlje salt pans, for more than 700 years engaged in salt production, are the largest coastal marsh wetlands and one of the most important Slovenian locality and tourist attractions. Nowadays, the Slovenian Coast is mainly visited for sun and beach tourism, with the majority of international tourists' visits made during the summer months (from June to August), whilst domestic tourists also visit the coast in February and April. The latter is due to the school holidays policy. More specifically, the policy specifies that school holidays take place five times a year for one week (at the end of October, the end of December, in February, end of April, and in summer), with the exception of the longer summer holidays, and that children are allowed an additional week of holidays upon parents' request. Further, the natural and historical sites along the Slovenian Coast (the Sečovlje Salina Nature Park and historical centres of Piran and Izola) offer various activities that can be consumed all year round. Sometimes, these are perceived as either attracting one-day visitors and thus adding to the crowding during the peak season, or as a solution for prolonging the stay of domestic and international tourists. Finally, the tourism industry is supplemented with casinos, which are very popular among international tourists.

The Slovenian Coast offers a minimum of 12,000 beds per day in various accommodation facilities. Its maximum capacity is approximately 23,000 beds available daily during summer months (from June to September). As shown in Figure 1, hotel beds are available all year round, with an evident drop in availability in winter months (from October till March). On the other hand, the availability of beds in camps and other accommodation is strongly weather-dependent: due to high temperatures, they were able to remain open for eight months in 2010, whilst in 2013 they were only open for six months. Together, they account for approximately 13,000 beds, which exceeds the monthly average availability of beds in hotels. 


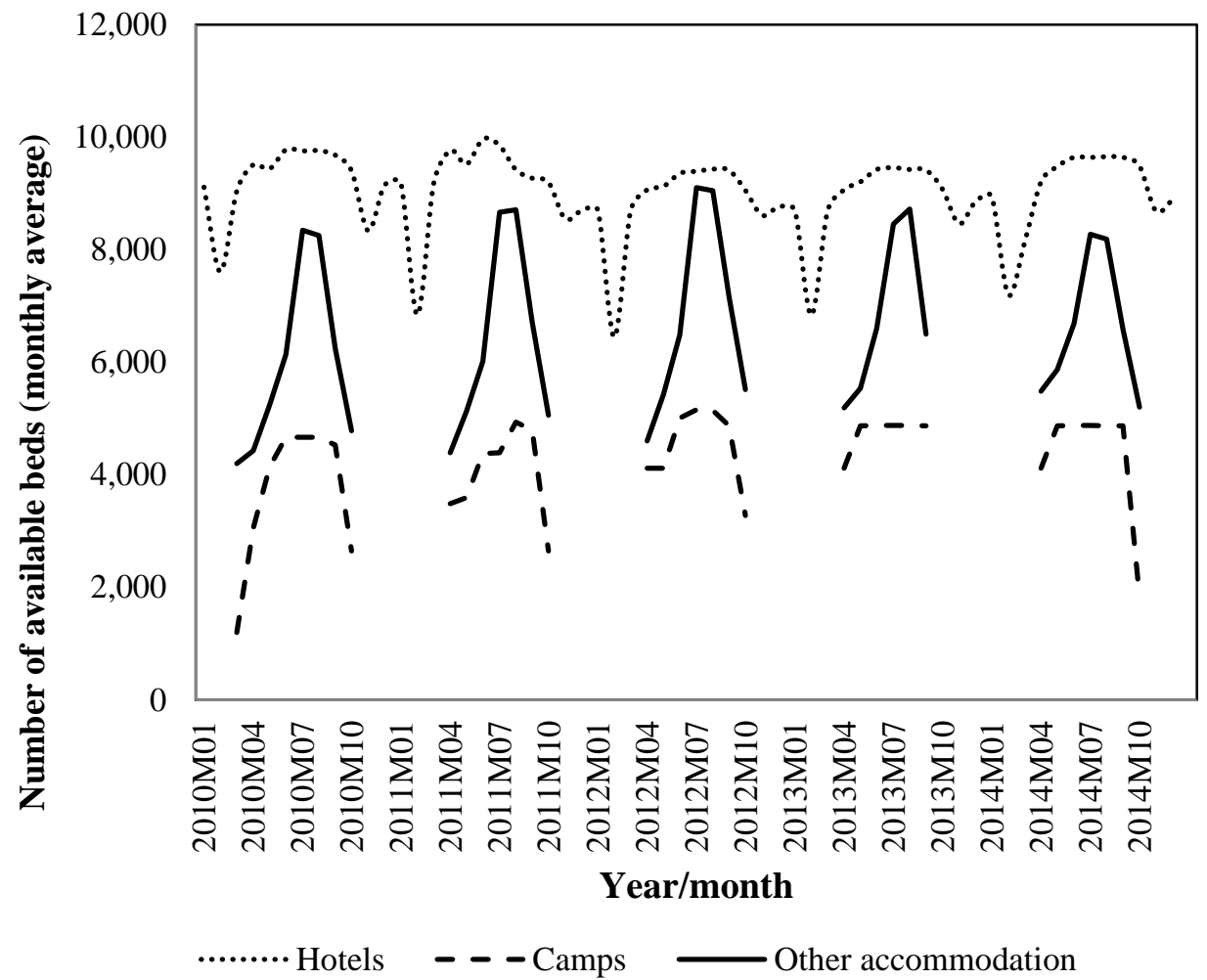

Fig. 1. Average monthly availability of beds by accommodation type, Slovenian Coast (20102014).

Source: Authors' own, based on data from the SORS (2015).

\section{Results on tourism seasonality on the Slovenian Coast}

\subsection{Occupancy rates and the Gini index}

The analysis of the occupancy rates showed that, on average, hotels have the lowest occupancy in January, November and December (from 13\% to 20\%). The peak of $82 \%$ is reached in summer months, whereas some occupancy fluctuations from March till May reflect the timing of the holidays (e.g. Easter holidays and Labour Day). The camps and other accommodation follow similar occupancy patterns as the hotels. At the beginning of the observed period, the camps' occupancy rates were higher than those for other accommodation $(51.79 \%$ and $40.17 \%$, respectively). The occupancy of the camps decreased from 2011 onwards, while it stayed very much the same for other accommodation. This is presumably due to the general decrease in visits by domestic tourists. Hence, Figure 2 represents the occupancy rate results for each accommodation category. 


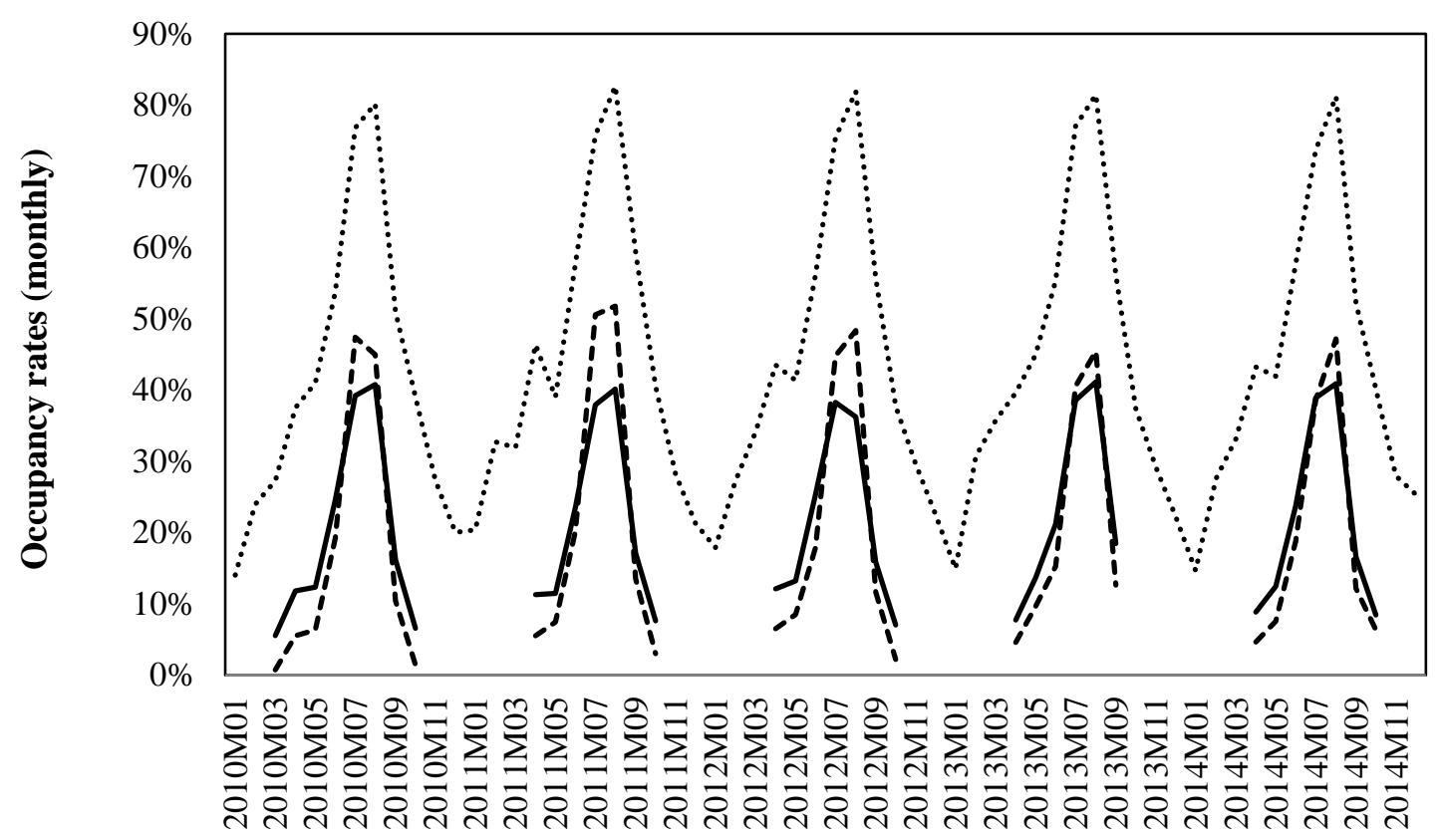

Year/month

Hotels

- Camps

Other accommodation

Fig. 2. Occupancy rates by accommodation, Slovenian Coast (2010-2014).

Source: Authors' own, based on data from the SORS (2015).

Moreover, tourism demand is at its lowest in the winter months, i.e. from January to March, and during November and December. This is very typical for a sun and beach tourism destination like the Slovenian Coast. The peak occurs in the summer months from June to September, where July and August take turns on 'the title' of the month with the highest number of overnight stays. Over the observed period, annual overnight stays did not increase dramatically, also explaining why the Gini index remained mostly unchanged $(\mathrm{G}=0.37)$. In Figure 3, we present the monthly number of overnight stays and corresponding annual Gini indices. 


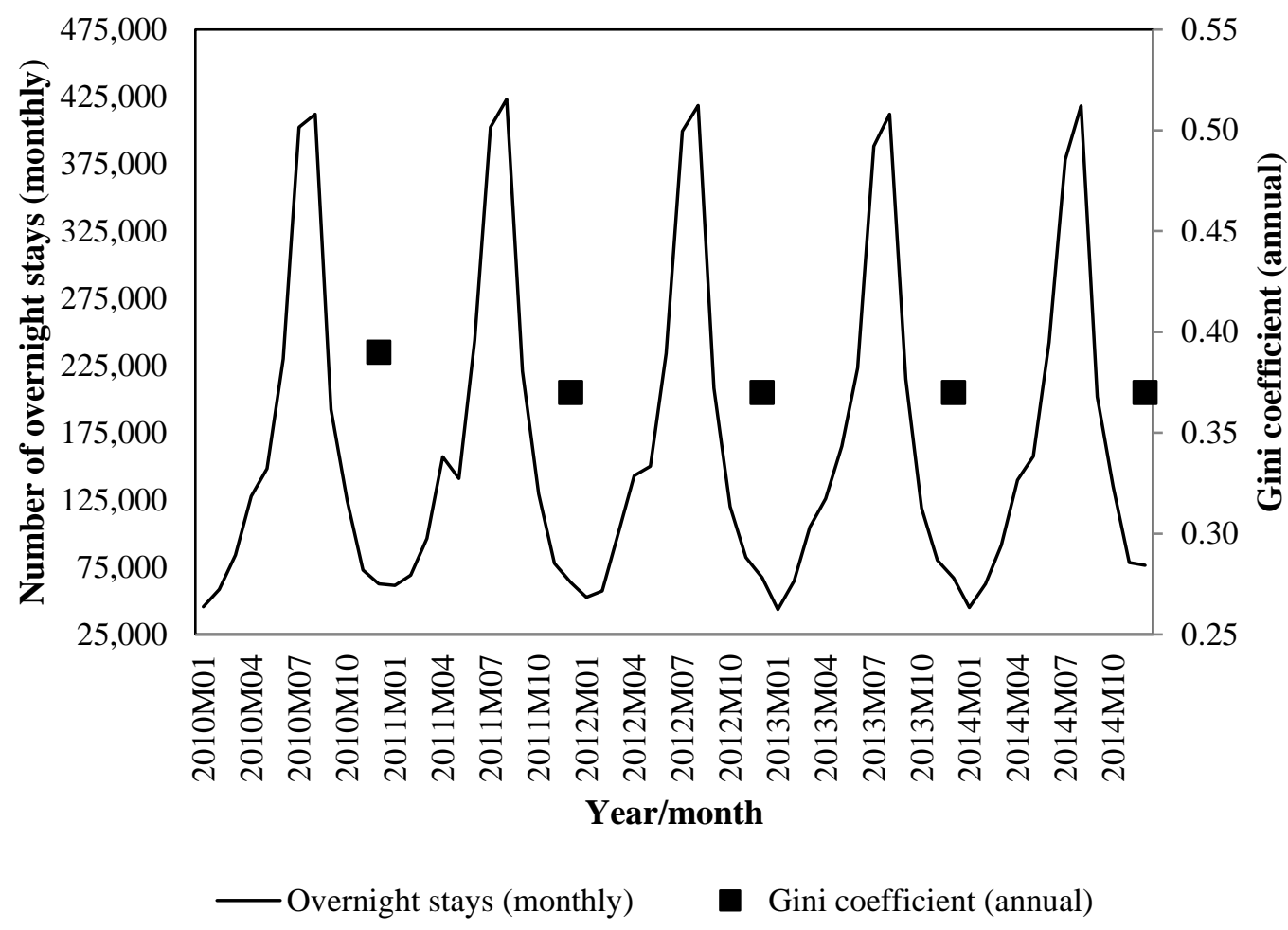

Fig. 3. Overnight stays per month and annual Gini coefficients, Slovenian Coast (2010-2014). Source: Authors' own, based on data from the SORS (2015).

\subsection{Contribution of domestic and international tourists to the seasonality}

The analysis of the decomposed Gini index (see Table 1) showed that the seasonal concentration of domestic tourists fell from 0.384 in 2010 to 0.309 in 2014. This is chiefly influenced by their overall drop in the number of overnight stays on the Slovenian Coast due to their increased interest in travelling abroad. This goes hand in hand with the reduction in their average annual length of stay and contribution to the total concentration (from 0.48 in 2010 to 0.35 in 2014) of the total overnight stays at the destination as well as to overnight stays at hotels (from 0.248 in 2010 to 0.166 in 2014), camps (from 0.593 in 2010 to 0.467 in 2014) and other accommodation (from 0.448 in 2010 to 0.371 in 2014). However, domestic tourists contributed more than $50 \%$ to the seasonal concentration in camps and other accommodation in 2014. Further, the results on the relative marginal effects suggest the relative increase in their overnight stays would not add substantially to the seasonality.

On the other hand, international tourists accounted for more than $60 \%$ of all overnight stays in hotels, with an evident cumulative increase in overnight stays in camps (13\%) and other accommodation (12\%) over the five-year period. This is not at the expense of hotels, but is based on their overall increase in overnight stays at the destination. However, international tourists' contribution to the total concentration accounted for $83 \%$ for hotels, $48 \%$ for camps and $46 \%$ for other accommodation in 2014. Yet, interestingly, their length of stay at the destination and in different accommodation facilities was decreasing. The analysis shows their relative marginal effects were all positive in 2014, suggesting that a relative increase in overnight stays by international tourists would substantially increase the overall seasonal concentration along the Slovenian Coast. 
Table 1. Decomposition of the Gini index for domestic and international tourists, Slovenian Coast (2010-2014)

\begin{tabular}{|c|c|c|c|c|c|c|c|c|c|c|c|c|c|}
\hline \multirow{2}{*}{$\begin{array}{l}\text { Year/accommodation } \\
\text { type }\end{array}$} & \multicolumn{2}{|c|}{$\begin{array}{l}\text { Length of } \\
\text { stay in days } \\
\text { (Mean) }\end{array}$} & \multicolumn{3}{|c|}{ Gini index } & \multicolumn{2}{|c|}{$\begin{array}{c}\text { Market } \\
\text { share }\end{array}$} & \multicolumn{2}{|c|}{$\begin{array}{l}\text { Gini } \\
\text { correlation }\end{array}$} & \multicolumn{2}{|c|}{$\begin{array}{c}\text { Contribution } \\
\text { to total } \\
\text { concentration }\end{array}$} & \multicolumn{2}{|c|}{$\begin{array}{c}\text { Relative marginal } \\
\text { effect }\end{array}$} \\
\hline & Ld & $\mathbf{L i}$ & $\mathbf{G}$ & Gd & Gi & Sd & $\mathbf{S i}$ & Rd & $\mathbf{R i}$ & Cd & $\mathbf{C i}$ & RMEd & RMEi \\
\hline \multicolumn{14}{|l|}{2010} \\
\hline Total & 3.47 & 3.17 & 0.386 & 0.384 & 0.396 & 0.49 & 0.51 & 0.988 & 0.989 & 0.48 & 0.52 & $-0.86 \%$ & $0.73 \%$ \\
\hline Hotels & 3.45 & 3.19 & 0.301 & 0.248 & 0.346 & 0.41 & 0.59 & 0.954 & 0.988 & 0.33 & 0.66 & $-8.87 \%$ & $7.88 \%$ \\
\hline Camps $*$ & 3.46 & 2.64 & 0.573 & 0.593 & 0.559 & 0.65 & 0.35 & 0.994 & 0.976 & 0.67 & 0.33 & $1.78 \%$ & $-1.69 \%$ \\
\hline Other accommodation* & 3.84 & 2.97 & 0.463 & 0.448 & 0.499 & 0.70 & 0.30 & 0.999 & 0.995 & 0.68 & 0.32 & $-2.34 \%$ & $2.17 \%$ \\
\hline \multicolumn{14}{|l|}{2011} \\
\hline Total & 3.44 & 3.12 & 0.366 & 0.344 & 0.395 & 0.46 & 0.54 & 0.986 & 0.992 & 0.43 & 0.58 & $-3.41 \%$ & $3.87 \%$ \\
\hline Hotels & 3.44 & 3.12 & 0.272 & 0.182 & 0.341 & 0.39 & 0.61 & 0.914 & 0.991 & 0.2 & 0.76 & $-15.09 \%$ & $14.97 \%$ \\
\hline Camps** & 3.54 & 2.55 & 0.502 & 0.506 & 0.495 & 0.64 & 0.36 & 0.998 & 0.993 & 0.64 & 0.35 & $0.38 \%$ & $-0.76 \%$ \\
\hline Other accommodation $* *$ & 3.58 & 2.68 & 0.414 & 0.415 & 0.433 & 0.65 & 0.35 & 0.996 & 0.987 & 0.65 & 0.36 & $-0.05 \%$ & $1.10 \%$ \\
\hline \multicolumn{14}{|l|}{2012} \\
\hline Total & 3.42 & 3.05 & 0.372 & 0.335 & 0.407 & 0.44 & 0.56 & 0.987 & 0.994 & 0.39 & 0.61 & $-4.80 \%$ & $4.92 \%$ \\
\hline Hotels & 3.44 & 3.16 & 0.276 & 0.171 & 0.348 & 0.37 & 0.63 & 0.903 & 0.993 & 0.21 & 0.79 & $-16.24 \%$ & $15.84 \%$ \\
\hline Camps** & 3.57 & 2.71 & 0.491 & 0.489 & 0.499 & 0.62 & 0.38 & 0.998 & 0.995 & 0.61 & 0.39 & $-0.40 \%$ & $0.43 \%$ \\
\hline Other accommodation $* *$ & 3.60 & 2.80 & 0.402 & 0.392 & 0.430 & 0.60 & 0.40 & 0.993 & 0.988 & 0.58 & 0.42 & $-2.02 \%$ & $2.24 \%$ \\
\hline \multicolumn{14}{|l|}{2013} \\
\hline Total & 3.39 & 3.11 & 0.370 & 0.326 & 0.412 & 0.43 & 0.57 & 0.981 & 0.992 & 0.37 & 0.63 & $-5.79 \%$ & $5.97 \%$ \\
\hline Hotels & 3.43 & 3.21 & 0.280 & & 0.354 & 0.37 & & 3 & & 0.20 & 0.79 & $-16.89 \%$ & $16.10 \%$ \\
\hline Camps ${ }^{* * *}$ & 3.61 & 2.68 & 0.393 & 0.411 & 0.390 & 0.58 & 0.42 & 0.994 & 0.987 & 0.61 & 0.41 & $2.20 \%$ & $-0.91 \%$ \\
\hline Other accommodation $* * *$ & 3.70 & 3.02 & 0.368 & 0.350 & 0.422 & 0.59 & 0.41 & 0.991 & 0.985 & 0.55 & 0.47 & $-3.42 \%$ & $5.28 \%$ \\
\hline \multicolumn{14}{|l|}{2014} \\
\hline Total & 3.29 & 2.92 & 0.367 & 0.309 & 0.418 & 0.42 & 0.58 & 0.976 & 0.993 & 0.35 & 0.66 & $-7.45 \%$ & $7.51 \%$ \\
\hline Hotels & 3.30 & 2.99 & 0.279 & 0.166 & 0.370 & 0.37 & 0.63 & 0.848 & 0.989 & 0.19 & 0.83 & $-18.29 \%$ & $19.80 \%$ \\
\hline Camps** & 3.44 & 2.69 & 0.473 & 0.467 & 0.480 & 0.52 & 0.48 & 0.994 & 0.993 & 0.51 & 0.48 & $-0.98 \%$ & $0.33 \%$ \\
\hline Other accommodation $* *$ & 3.47 & 2.70 & 0.397 & 0.371 & 0.446 & 0.58 & 0.42 & 0.993 & 0.989 & 0.54 & 0.46 & $-4.20 \%$ & $4.57 \%$ \\
\hline
\end{tabular}

Note: $d=$ domestic tourists; i=international tourists; $\mathrm{L}=$ length of stay; $\mathrm{G}=$ the Gini index; $\mathrm{S}=$ market share; $\mathrm{R}=$ Gini correlation; $\mathrm{C}=$ contribution to total concentration; $\mathrm{RME}=$ relative marginal effects; *opened for 8 months; **opened for 7 months; ***opened for 6 months.

Source: Authors' own, based on data from the SORS (2015).

\subsection{Seasonal variations of the top five tourism markets in 2014}

Further, decomposition of the Gini index by the top five tourism markets in 2014 better clarifies the tourist influx in different accommodation facilities. The results showed that domestic tourists accounted for $42 \%$ of all tourists at the destination, followed by Italians (12\%), Austrians (12\%), Germans (8\%) and Russians (4\%) (see Table 2).

The analysis of tourists from Italy and Austria, two of Slovenia's neighbouring countries, showed their annual seasonal concentration is the lowest $(\mathrm{G}=0.258$ and $\mathrm{G}=0.361$, respectively) compared to other international markets. The yearly average length of stay on the Slovenian Coast was 2.41 days for Italians and 3.16 days for Austrians, where Austrians were far keener on staying at the destination in May and September. Both Italians (86.04\%) and Austrians $(88.22 \%)$ mostly stayed in hotels, with minimal overnight stays in camps $(4.97 \%$ and $3.25 \%$, respectively) and other accommodation facilities (9.17\% and $8.53 \%$, respectively) (see Figure 4). The analysis of the relative marginal effects for both markets showed that an increase in overnight stays by Italians (RME=-3.06\%) and Austrians (RME=-1.33\%) would not contribute to the destination's overall seasonal concentration. 
Table 2. Decomposition of the Gini index by the top five tourism markets, Slovenian Coast (2014)

\begin{tabular}{|c|c|c|c|c|c|c|}
\hline $\begin{array}{l}\text { Accommodation } \\
\text { type/market }\end{array}$ & $\begin{array}{l}\text { Length of } \\
\text { stay in days } \\
\text { (Mean) } \\
\text { (L) }\end{array}$ & $\begin{array}{c}\text { Gini } \\
\text { index } \\
(\mathbf{G k})\end{array}$ & $\begin{array}{c}\text { Market } \\
\text { share } \\
\text { (Sk) }\end{array}$ & $\begin{array}{l}\text { Gini } \\
\text { correlation } \\
(\mathbf{R k})\end{array}$ & $\begin{array}{c}\text { Contribution to } \\
\text { total } \\
\text { concentration } \\
(\mathbf{C k})\end{array}$ & $\begin{array}{c}\text { Relative } \\
\text { marginal } \\
\text { effect } \\
(\text { RMEk) }\end{array}$ \\
\hline \multicolumn{7}{|l|}{ TOTAL } \\
\hline Slovenia & 3.29 & 0.309 & 0.42 & 0.976 & $34.96 \%$ & $-6.20 \%$ \\
\hline Italy & 2.41 & 0.258 & 0.12 & 0.742 & $6.40 \%$ & $-3.06 \%$ \\
\hline Austria & 3.16 & 0.361 & 0.12 & 0.892 & $10.95 \%$ & $-1.33 \%$ \\
\hline Germany & 3.83 & 0.503 & 0.08 & 0.887 & $9.79 \%$ & $2.12 \%$ \\
\hline Russia & 5.47 & 0.528 & 0.04 & 0.979 & $6.02 \%$ & $2.45 \%$ \\
\hline Other international tourists & 2.71 & 0.537 & 0.20 & 0.978 & $29.24 \%$ & $12.57 \%$ \\
\hline \multicolumn{7}{|l|}{ HOTELS } \\
\hline Slovenia & 3.30 & 0.166 & 0.37 & 0.848 & $18.61 \%$ & $-9.22 \%$ \\
\hline Italy & 2.48 & 0.225 & 0.15 & 0.623 & $7.61 \%$ & $-3.78 \%$ \\
\hline Austria & 3.20 & 0.334 & 0.15 & 0.904 & $16.18 \%$ & $1.33 \%$ \\
\hline Germany & 4.11 & 0.440 & 0.08 & 0.884 & $11.02 \%$ & $4.36 \%$ \\
\hline Russia & 5.58 & 0.528 & 0.05 & 0.949 & $9.47 \%$ & $7.55 \%$ \\
\hline Other international tourists & 2.73 & 0.484 & 0.20 & 0.959 & $33.04 \%$ & $21.99 \%$ \\
\hline \multicolumn{7}{|l|}{ CAMPS $* *$} \\
\hline Slovenia & 3.44 & 0.467 & 0.52 & 0.994 & $51.18 \%$ & $-0.96 \%$ \\
\hline Italy & 2.81 & 0.504 & 0.06 & 0.965 & $6.17 \%$ & $0.17 \%$ \\
\hline Austria & 2.78 & 0.381 & 0.04 & 0.963 & $3.21 \%$ & $-0.72 \%$ \\
\hline Germany & 2.78 & 0.443 & 0.11 & 0.884 & $9.42 \%$ & $-1.62 \%$ \\
\hline Russia & 3.19 & 0.566 & 0.00 & 0.970 & $0.41 \%$ & $0.07 \%$ \\
\hline Other international tourists & 2.56 & 0.517 & 0.26 & 0.997 & $28.29 \%$ & $2.53 \%$ \\
\hline \multicolumn{7}{|c|}{ OTHER ACCOMMODATION $* *$} \\
\hline Slovenia & 3.47 & 0.371 & 0.58 & 0.993 & $54.09 \%$ & $-3.90 \%$ \\
\hline Italy & 1.88 & 0.383 & 0.06 & 0.912 & $5.05 \%$ & $-0.61 \%$ \\
\hline Austria & 2.73 & 0.359 & 0.05 & 0.976 & $4.84 \%$ & $-0.58 \%$ \\
\hline Germany & 3.36 & 0.495 & 0.07 & 0.877 & $8.06 \%$ & $0.75 \%$ \\
\hline Russia & 5.69 & 0.476 & 0.03 & 0.987 & $3.01 \%$ & $0.55 \%$ \\
\hline Other international tourists & 2.66 & 0.489 & 0.21 & 0.974 & $24.66 \%$ & $4.93 \%$ \\
\hline
\end{tabular}

Note: $\mathrm{k}=$ specific market; $\mathrm{L}=$ length of stay; $\mathrm{G}=$ the Gini index; $\mathrm{S}=$ market share; $\mathrm{R}=$ Gini correlation; $\mathrm{C}=$ contribution to total concentration; RME=relative marginal effects; **opened for 7 months

Source: Authors' own, based on data from the SORS (2015).

In contrast, German tourists with only an $8 \%$ annual share of total overnight stays contributed $9.79 \%$ to the total seasonal concentration and their Gini index was above 0.50 for the Slovenian Coast in general. In addition, their relative marginal effect was positive $(\mathrm{RME}=2.12 \%)$, denoting that a small relative increase would further add to the seasonality. This is because German tourists mainly visited the destination from June to September. When distinguishing the three types of accommodation facilities, Germans had the lowest Gini index for hotels $(\mathrm{G}=0.440)$ and the highest for other accommodation $(\mathrm{G}=0.495)$. They represented a roughly $8 \%$ market share in hotels and other accommodation, with an average annual length of stay of 4.11 days in hotels and 3.36 days in other accommodation. However, for both accommodation types, their relative marginal effect was positive ( $\mathrm{RME}=4.36 \%$ for hotels and $\mathrm{RME}=0.75 \%$ for other accommodation), whilst for camps it was negative (RME $=-1.62 \%$ ). This indicates that a further relative increase in German tourists only in camps would not add to the seasonality. 


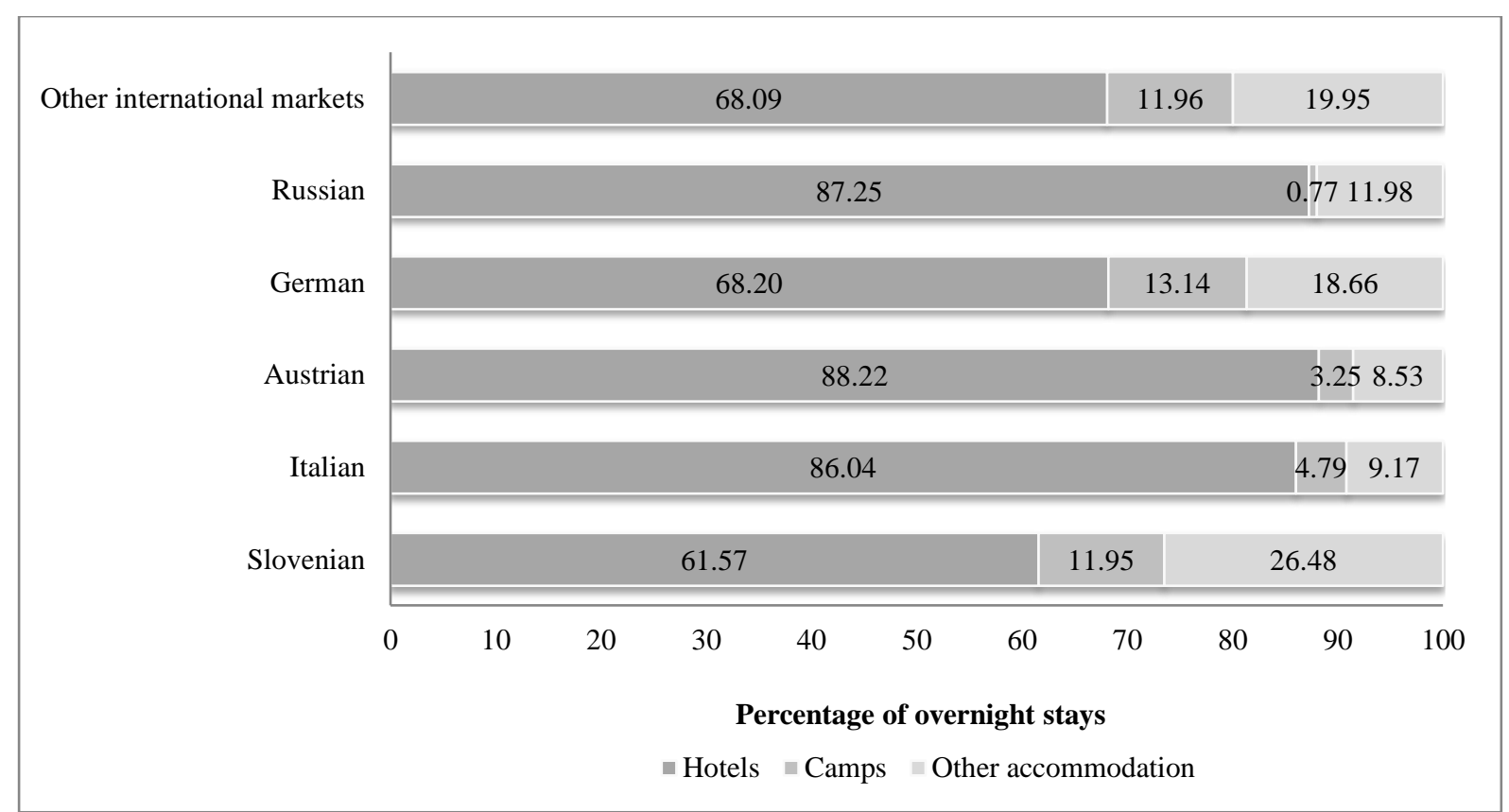

Fig. 4. Accommodation by the top five markets, Slovenian Coast (2014).

Source: Authors' own, based on data from the SORS (2015).

The analysis also showed that Russians had one of the highest Gini indices for total overnight stays $(\mathrm{G}=0.528)$ as well as for hotels and camps $(\mathrm{G}=0.528$ and $\mathrm{G}=0.566$, respectively). Russian visits to the Slovenian Coast made predominately in July and August are to be blamed for these Gini indices. Hand in hand, their relative increase would add to the seasonality at the destination $(\mathrm{RME}=2.45 \%)$, as well as to hotels ( $\mathrm{RME}=7.55 \%)$. This is because the majority of Russian tourists stayed in hotels $(87.25 \%)$, while only a small number stayed in camps $(0.77 \%)$ and other accommodation $(11.98 \%)$. On the other hand, on average Russian tourists stayed more than 5 days at the destination, in hotels and in other accommodation, which is the longest among the top five markets.

\section{Implications for counter-seasonal responses on the Slovenian Coast}

Seasonality is a very complex phenomenon and strategies for mitigating its magnitude have been of great interest to tourism managers and policy-makers in numerous tourism destinations (Butler, 2001; Koenig-Lewis \& Bischoff, 2005), including the Slovenian Coast. During the observed period (2010-2014), annual overnight stays did not show a high growth rate, also explaining why the Gini index remained mostly unchanged at the value of 0.37 . For comparison, the Gini index calculations for other mainland coastal sun and beach destinations were lower; for Costa del Sol $(\mathrm{G}=0.20)$ (Fernandez-Morales \& Mayorga-Toledano, 2008), for Andalusia ( $\mathrm{G}=0.22)$ (Cisneros-Martínez \& Fernández-Morales, 2013), and for Seville $(\mathrm{G}=0.12)$ (Duro, 2016). Further, higher values were calculated for island-based destination such as the Balearic Islands $(\mathrm{G}=0.40)$ (Duro, 2016; Sastre, Hormaeche, \& Villar, 2015) and Croatian destinations $(\mathrm{G}=0.60)$ (Kožič et al., 2013). In general, the tourism seasonality of Slovenian tourism is quite high compared to other mainland coastal destinations.

\subsection{Strategies for the domestic market}

The findings showed that domestic tourists are the least seasonal. This is in line with other researchers' findings demonstrating that domestic visits are more dispersed and more frequent (Duro, 2016; Kožić et al., 2013; Sastre et al., 2015). The analysis revealed a clear downward 
trend in domestic tourists' overnight stays in the period 2010-2014, which produces negative RME values. The data showed that overnight stays have two peaks, one in February and the other in July. Indeed, the national policy on school holidays seems to benefit Slovenian sun and beach tourism destinations by ensuring a domestic tourist influx in periods otherwise unappealing to international tourists. Marketing strategies for customising school holiday tourism products already established by hospitality managers along the Slovenian Coast are a prime example of a response to seasonality. However, there is a need to refresh them since domestic overnight stays are in decline. One suggestion is to partner up with local museums and natural parks to offer educational trips for children, whilst parents would be offered wellness and spa activities. Moreover, other demographic groups should be considered, such as students and seniors. In the case of the former, a 'spring-break relaxation package' is suggested as a tourism product tailor-made for graduate students, with the potential to increase visits from March to June. Another alternative is an 'active ageing package' for seniors, a combination of outdoor and indoor activities beneficial for managing chronic conditions like rheumatism, dropsy and obesity, for which Portorož has been famous since the $13^{\text {th }}$ century.

\subsection{Strategies for the neighbouring markets}

Tourists from Italy and Austria, two countries neighbouring Slovenia, were shown to represent the underexploited potential of the Slovenian Coast. The negative findings on relative marginal effects $\left(\mathrm{RME}_{\text {Italy }}=-3.06 \%\right.$ and $\mathrm{RME}_{\text {Austria }}=-1.33 \%$, respectively) suggest that an increase in overnight stays by Italian and Austrian tourists would further add to the seasonality in general. These results confirm Butler's (1998) suggestion that the closest markets are more attractive holiday destinations than the distant ones.

This study showed that both neighbouring markets exhibit similar characteristics worth mentioning. Camps and other accommodation are the two nonpopular categories for both markets. More specifically, Italian tourists predominately stayed in hotels (86.04\%), with a $15 \%$ market share and an average length of stay of 2.48 days. Similarly, Austrian tourists also chiefly stayed in hotels (88.22\%), with the same market share as Italians (15\%), but a slightly longer stay length of 3.20 days. With respect to the scheduling of their visits, the two neighbouring markets visited the Slovenian Coast mostly during summer, in July and August. The only differences between them lay in the two smaller peaks of Italian overnight stays in April and December, while Austrians stretched their visits from May to September. This is reflected in the total Italian Gini index of 0.258, which was the lowest among the top five markets in 2014, while the total Austrian Gini index was 0.361. These differences are due to holidays. That is, Italian tourists scheduled their trips to the Slovenian Coast at the time of national holidays like Easter and Christmas in April and December, whilst Austrians opted to visit during their national school holidays in May. National holidays and the Austrian school holidays are government regulated; therefore, the timeframe of potential Italian and Austrian visits is known in advance. With this in mind, counter-seasonal responses designed for attracting Italian and Austrian tourists could be well developed and planned in advance. Further, it is suggested that tourism products combine the activities most desired by Italian and Austrian tourists, such as wellness, gastronomy, gambling, and outdoor activities. Moreover, due to the proximity of these two markets, these activities could become core products for socalled 'prolonged weekend-hotel stays' that would encourage Italian and Austrian tourists to make all-year-round weekend visits during other national holidays specific to these two countries. This type of tourism product also opens opportunities for the managers of other accommodation facilities such as tourist farms with accommodation to attract Italian and Austrian tourists with tourism products that couple wellness activities with traditional and local gastronomy. 


\subsection{Strategies for distant markets}

In this study, Germany and Russia were two distant markets for tourism accommodation on the Slovenian Coast. The analysis showed they make a stronger contribution to the seasonality $\left(\mathrm{G}_{\text {Germany }}=0.503\right.$ and $\left.\mathrm{G}_{\mathrm{Russia}}=0.528\right)$. However, further analysis of overnight stays in different accommodation facilities gave insights into how to carefully approach these markets so as not to further add to the seasonality.

German tourists' overnight stays in different accommodation facilities are the most versatile among international tourists. Only $68.20 \%$ stayed in hotels, while $13.14 \%$ stayed in camps and $18.66 \%$ stayed in other accommodation. These overnight stays were stretched from May till September, with May and July being the months with the lowest number of overnight stays. German tourists' length of stay in hotels and other accommodation ranged from 3 to 4 days on average, creating opportunities for extending their stay. This could be accomplished through price incentives for visits in spring and autumn in combination with the development of tailor-made tourism products offered by camps and other accommodation. For example, spring and autumn stays in camps and tourist farms with accommodation could be paired with activities such as horse-riding, educational field trips to the Sečovlje Salina Park, swimming lessons etc at lower prices for families with children.

Russian tourists' overnight stays very strongly contributed to the seasonality $(\mathrm{G}=0.528)$. This is because the majority of Russian overnight stays were seen in July and August, and in hotels $(87.25 \%)$. However, it is the length of stay and the luxurious lifestyle that makes the Russian market so appealing. Russian tourists stayed at the destination for more than 5 days on average, which far exceeds the length of stay made by other tourists. By leveraging their luxurious lifestyle, local hotels like Lifeclass Hotels \& Spa and Kempinski Palace Portorož offered wellness, different medical services and fine dining, which were all well accepted by Russian tourists. This is a good example for other four- or five-star hotels on the Slovenian Coast to follow, or even by topping up the offer with price incentives for luxurious services to attract Russian tourists in the pre-and post-season (i.e. April-May and September-October) or during their national holidays.

\section{Conclusions}

Seasonality has long been recognised as a problem for tourism destinations, especially those over characterised by sun and beach tourism. Hence, the counter-seasonal responses remain the backbone of such destinations' strategic development. Previous research focused on hotel overnight stays and some surveys addressed the differences in tourism activity between the different tourist markets. However, other accommodation facilities, such as camps, private accommodation, tourism farms, marinas, youth hostels etc, that are important sources of overnight stays in many tourism destinations have not been addressed.

In this paper, the seasonality is surveyed by using a decomposition of the Gini index, by differentiating between three accommodation type categories, e.g. hotels, camps and other accommodation facilities, across the top five source markets. In the case of Slovenian Coastal tourism, it has been demonstrated that the overnights at camps and other accommodation facilities are an important element of the seasonal concentration. Seasonal concentration exhibited stability during the analysed period 2010-2014. The G value of 0.37 places the Slovenian Coast in the higher seasonality category among Mediterranean mainland coastal destinations. Domestic tourists are the least seasonal, followed by tourists from Italy and Austria. This indicates that proximity of the market of origin is an important factor for reducing destination's seasonality (Butler, 1998). Moreover, Italian and Austrian tourists visit Slovenia during national holidays, demonstrating how school and industrial holidays in outbound countries play an important role in the seasonality of the recipient tourism destination (Rosselló 
\& Sansó, 2017). On the other side, this study also demonstrated that the most seasonal markets are Germany and Russia. There is the need to develop specific tourism products that would attract German and Russian visitors also outside the peak summer months.

In order to manage destination's seasonality and prepare attractive out-of-season tourist products for specific markets and their segments, more information on visitors' seasonal behaviour and profiles needs to be incorporated into the future analyses. More specifically, further studies should differentiate between types of visitors (i.e. repeat, first time), tourists' demographic characteristics (i.e. age, education, marital status, employment, number of family members), travel motivation (i.e. business, leisure, and second-home owners) and survey main tourist activities. More in-depth understanding of seasonal behaviour of visitors from different markets could inform counter-seasonal responses and improve sustainability of seasonal destinations.

\section{REFERENCES}

Allcock, J. B. (1994). Seasonality. In S. F. Witt, \& L. Moutinho (Eds.), Tourism marketing and management handbook (pp. 86-92), Cambridge, UK: Prentice Hall.

Andriotis, K. (2005). Seasonality in Crete: Problem or a way of life? Tourism Economics, $11(2), 207-224$.

Ball, R. M. (1989). Some aspects of tourism, seasonality, and local labour markets. Area, 21(1), 35-45.

BarOn, R. R. V. (1975). Seasonality in tourism - a guide to the analysis of seasonality and trends for policy making. (Technical Series No. 2). London: The Economist Intelligence Unit.

Baum, T., \& Hagen, L. (1999). Responses to seasonality: The experiences of peripheral destinations. International Journal of Tourism Research, 1(Sept/Oct), 299-312.

Butler, R. (1998). Seasonality in tourism: Issues and implications. The Tourist Review, 53(3), $18-24$.

Butler, R. W. (2001). Seasonality in tourism: Issues and implications. In T. Baum, \& S. Lundtorp (Eds.), Seasonality in tourism (pp. 5-22), Oxford, UK: Elsevier.

Butler, R. W., \& Mao, B. (1997). Seasonality in tourism: Problems and measurement. In P. E. Murphy (Ed.), Quality management in urban tourism (pp. 9-23), Chichester, UK: Wiley.

Cannas, R. (2012). An overview of tourism seasonality: Key concepts and policies. Almatourism - Journal of Tourism, Culture and Territorial Development, 3(5), 40-58.

Cisneros-Martínez, J. D., \& Fernández-Morales, A. (2013). Cultural tourism as tourist segment for reducing seasonality in a coastal area: The case study of Andalusia. Current Issues in Tourism, 18(8), 765-784.

Clarke, A. (1981). Coastal development in France. Annals of Tourism Research, 8(3), 447461.

Commons, J., \& Page, S. (2001). Managing seasonality in peripheral tourism regions: The case New Zealand. In T. Baum \& S. Lundtorp (Eds.), Seasonality in tourism (pp. 153172), New York: Pergamon.

Cuccia, T., \& Rizzo, I. (2011). Tourism seasonality in cultural destinations: Empirical evidence from Sicily. Tourism Management, 32(3), 589-595.

Cunado, J., Gil-Alana, L. A., \& Péres De Gracia, F. (2004). Modelling monthly Spanish tourism: A seasonal fractionally integrated approach. Tourism Economics, 10(1), 79-94.

Cunado, J., Gil-Alana, L. A., \& Perez de Garcia, F. (2005). The nature of seasonality in Spanish tourism time series. Tourism Economics, 11(4), 483-499. 
De Cantis, S., Ferrante, M., \& Vaccina, F. (2011). Seasonal pattern and amplitude - A logical framework to analyse seasonality in tourism: An application to bed occupancy in Sicilian hotels. Tourism Economics, 17(3), 655-675.

Duro, J. A. (2016). Seasonality of hotel demand in the main Spanish provinces: Measurements and decomposition exercises*. Tourism Management, 52, 52-63.

Fernandez-Morales, A. (2003). Decomposing seasonal concentration. Annals of Tourism Research, 30(4), 942-956.

Fernandez-Morales, A., Cisneros-Martinez, J. D., \& McCabe, S. (2016). Seasonal concentration of tourism demand: Decomposition analysis and marketing implications. Tourism Management, 56, 172-190.

Fernandez-Morales, A., \& Mayorga-Toledano, M. C. (2008). Seasonal concentration of the hotel demand in Costa del Sol: A decomposition by nationalities. Tourism Management, 29(5), 940-949.

Goulding, P. J., Baum, T. , \& Morrison, A. J. (2005). Seasonal trading and lifestyle motivation. Journal of Quality Assurance in Hospitality \& Tourism, 5(2-4), 209-238.

Grant, M., Human, B., \& Le Pelley, B. (1997). Seasonality. In Insights - Tourism Intelligence Papres. London: British Tourist Authority, English Tourist Board.

Halpern, N. (2011). Measuring seasonal demand for Spanish airports: Implications for counter-seasonal strategies. Research in Transportation Business and Management, $1(1), 47-54$.

Hartman, R. (1986). Tourism, seasonality and social change. Leisure Studies, 5(1), 25-33.

Jang, S. C. (2004). Mitigating tourism seasonality - A quantitative approach. Annals of Tourism Research, 31(4), 819-836.

Jeffrey, D., \& Hubbard, N. J. (1988). Temporal dimensions and regional patterns of hotel occupancy performance in England: A time series analysis of midweek and weekend occupancy rates in 266 hotels, in 1984 and 1985. International Journal of Hospitality Management, 7(1), 63-80.

Karamustafa, K., \& Ulama, S. (2010). Measuring the seasonality in tourism with the comparison of different methods. EuroMed Journal of Business, 5(2), 191-214.

Koenig-Lewis, N., \& Bischoff, E. E. (2005). Seasonality research: The state of the art. International Journal of Tourism Research, 7(4-5), 201-219.

Kožić, I. (2013). Kolika je sezonalnost turizma u Hrvatskoj? Ekonomski Vjesnik, 26(2), 470480.

Kožić, I., Krešić, D., \& Boranić-Živoder, S. (2013). Analiza sezonalnosti turizma u Hrvatskoj primjenom metode Gini koeficijenta. Ekonomski pregled, 64(2), 159-182.

Krakover, S. (2000). Partitioning seasonal employment in the hospitality industry. Tourism Management, 21(5), 461-471.

Lerman, R. I., \& Yitzhaki, S. (1985). Income inequality effects in income source: A new approach and applications to the United States. The Review of Economics and Statistics, 67(1), 151-156.

Lundtorp, S. (2001). Measuring tourim seasonality. In T. Baum, \& S. Lundtorp (Eds.), Seasonality in tourism (pp. 23-50), Oxford, UK: Elsevier.

Manning, R. E., \& Powers, L. A. (1984). Peak and off-peak use: Redistributing the outdoor recreation/tourism load. Journal of Travel Research, 23(2), 25-31.

Mathieson, A., \& Wall, G. (1982). Tourism: Economic, physical and social impacts. London, UK: Longman.

Mihalič, T. (2011). Partnerstvo za trajnostni razvoj slovenskega turizma 2012-2016. Podlage za Strategijo razvoja in trženja slovenskega turizma 2012-2016. (Partnership for sustainable tourism development in Slovenia 2012-2016. Materials for slovenian development and marketing). Ljubljana, Slovenia: Institute for Tourism, Faculty of 
Economics \& Slovenian Tourism Board.

Mihalič, T. (2016). Sustainable-responsible tourism discourse - Towards "responsustable" tourism. Journal of Cleaner Production, 111, 461-470.

Mihalič, T., \& Kaspar, C. (1996). Umweltökonomie im tourismus (St. Galler beiträge zum tourismus und zur verkehrswirtschaft, 27). Bern: Paul Haupt.

Muir, F., \& Chester, G. (1993). Managing tourism to a seabird nesting island. Tourism Management, 14(2), 99-105.

Murphy, P. E. (1985). Tourism: A community approach. New York: Methuen.

Nadal, J. R., Font, A. R., \& Rossello, A. S. (2004). The economic determinants of seasonal patterns. Annals of Tourism Research, 31(3), 697-711.

Nunkoo, R., \& Ramkissoon, H. (2011). Developing a community support model for tourism. Annals of Tourism Research, 38(3), 964-988.

Pearce, D. G. (1989). Tourist development. Harlow: Longman.

Rosselló, J., \& Sansó, A. (2017). Yearly, monthly and weekly seasonality of tourism demand: A decomposition analysis. Tourism Management, 60, 379-389.

Sastre, M. A. G., Hormaeche, M. A., \& Villar, M. T. (2015). Are regional political decisions the key element in reducing seasonal variation in tourism? The case of the Balearic Islands. Tourism Economics, 21(6), 1207-1219.

Statistical Office of the Republic of Slovenia (2015). Retrieved 03.11.15 from: <http://www.stat.si/statweb/en/home/>

Tourism Piran-Portoroz. (2013). Portoroz History. Retrieved 01.12.16 from: <http://www.portoroz.si/en/portoroz-and-piran/portoroz/483/>

Trajkov, A., Biljan, J., \& Andreeski, C. (2016). Overview and characteristics of tourism seasonality in Ohrid. Economic Themes, 54(4), 485-498.

van der Werff, P. E. (1980). Polarizing implications of the Pescaia tourist industry. Annals of Tourism Research, 7(2), 197-223.

Volo, S. (2010). Research note: Seasonality in Sicilian tourism demand - An exploratory study. Tourism Economics, 16(4), 1073-1080.

Wanhill, S. R. C. (1980). Tackling seasonality: a technical note. International Journal of Tourism Management, 1(4), 243-245.

Weaver, D. B., \& Oppermann, M. (2000). Tourism Management. Brisbane, Australia: John Wiley and Sons.

Witt, S. F., \& Moutinho, L. (Eds.). (1994). Tourism marketing and management handbook. New York: Prentice Hall.

Yacoumis, J. (1980). Tackling seasonality. International Journal of Tourism Management, l(2), 84-98. 


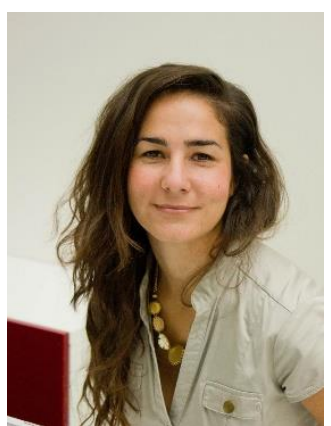

Dr. Tina Šegota is a lecturer at the Department of Marketing, Events and Tourism at the University of Greenwich. She holds a PhD in Marketing Communications from the Faculty of Social Sciences, University of Ljubljana, and she is also a PhD candidate in Tourism at the Faculty of Economics, University of Ljubljana. Her research interest is on seasonality and sustainable tourism development, with a passionate focus on local residents. She is also interested in destination image, self-congruity and destination advertising. She has published in leading journals and has co-authored several book chapters.

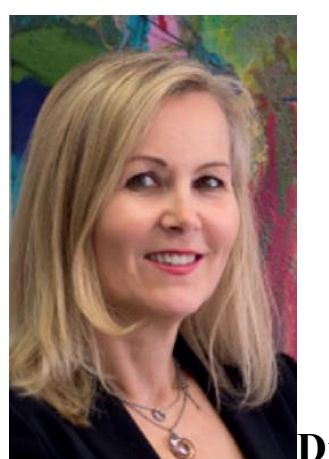

Dr. Tanja Mihalič is a professor for tourism economics and a vice dean for student affairs at the Faculty of Economics University of Ljubljana, Slovenia. She is also a head of Tourism Institute and an academic head of joint Erasmus Mundus European Master in Tourism Management program at the Faculty of Economics. Her research interests include tourism economics and management, environmental economics, competitiveness, policy, and sustainable tourism development. She has experience as adviser in sustainable and responsible tourism to national governments and EU and global bodies. Among others she is a counsellor of Ljubljana Tourism organization, an expert evaluator for the European Commission and the member of the UNWTO World Committee on Tourism Ethics. She is editorial board member or field editor of several international journals.

\footnotetext{
${ }^{\text {i }}$ Parahoteleria is an expression that denotes accommodation facilities other than hotels. The term is widely used in Germany and South-East Europe in order to distinguish hotels from other accommodation facilities.

ii Also called the Gini correlation coefficient.
} 